\title{
Differences in Covid-19 Mitigation Implementation in Urban and Rural Areas
}

\author{
Putu Indra Christiawan ${ }^{1}$, I Gede Astra Wesnawa ${ }^{1}$ \\ indra.christiawan@undiksha.ac.id, astra.wesnawa@undiksha.ac.id
}

${ }^{1}$ Universitas Pendidikan Ganesha, Indonesia

\begin{abstract}
The global Covid-19 pandemic is practically concentrated in urban areas. However, in some cases, this global virus has also spread in rural areas. As the capital city of Bali Province, Denpasar City represents urban areas, and its suburbs represent rural areas. There is a difference in the number of cases between the two regions, but it is not known whether there is a difference in mitigation between them. This study aims to analyze the differences in the implementation of Covid-19 mitigation between rural and urban areas. This research is exploratory research with in-depth interviews to collect data from key informants, and then analyzed descriptively qualitatively. The results show differences in the implementation of Covid-19 mitigation between urban and rural areas, both structural and non-structural mitigation. In structural mitigation, urban areas look more competent than rural areas. Meanwhile, in non-structural mitigation, urban areas appear to be more regulation-oriented than rural areas. The difference in mitigation has implications for the vulnerability of the region in the spread of Covid-19 cases.
\end{abstract}

Keywords: Covid-19; Structural Mitigation; Non-Structural Mitigation; Urban Areas; Rural Areas

\section{Introduction}

A disaster is an event or series of events that threaten and disrupt people's lives and livelihoods caused, either by natural factors/or non-natural factors or human factors, resulting in human casualties, environmental damage, property losses, and psychological impacts. The disaster can classifies into three categories, namely natural disasters, non-natural disasters, and social disasters. Non-natural disasters are disasters caused by events or a series of non-natural events, including technological failures, failed modernization, epidemics, and disease outbreaks.

One of the non-natural disasters that can threaten and disrupt the sustainability of people's lives is the COVID-19 pandemic (Corona Virus Disease 2019). Since the first case was reported in Wuhan at the end of 2019, this virus has spread in many countries in a short time. Then, WHO declared this virus a world pandemic [1].

As a new global catastrophe, COVID-19 has forced every country, region, and individual to react. Reactions to this new virus vary widely, but many replicate the efforts of other parties 
and regions. Each region has variations in terms of physiographic, social, and economical. Many studies have been related to COVID-19, identifying the source of disasters, testing their effectiveness, and community involvement [2], [3], but no research has yet been conducted which specifically examines the mitigation of COVID-19. Substantially the research related to disaster mitigation that has been carried out so far has not considered the characteristics of the area based on the level of urbanization as the basis for the study.

This study will discuss how the differences in mitigation carried out by the city and its hinterland area are based on the presence of cases of the spread of COVID-19. This study will also show whether the disaster mitigation carried out by each region is balanced and reveal which areas are more vulnerable to the spread of COVID- 19.

\section{Methods}

The research design used is primarily qualitative. This basic qualitative design is intended to produce an in-depth understanding of various disaster mitigation efforts carried out in each region in anticipation of the spread of Covid-19 cases. This qualitative design is an approach that is used to understand and interpret social phenomena in their natural environment, which in this study is the community's response to the danger of epidemics based on the characteristics of the region. The use of this design was mainly taken to answer specific research objectives. This type of research is also useful to further enhance understanding and crystallize research problems developed [4].

The scope of this research is focused in Denpasar City and its hinterlands, especially in the urban and rural areas. The subjects chosen in this study were key informant spread throughout Denpasar City and its hinterlands. An online questionnaire is applied for data collection. The main purpose of this questionnaire is to understand the respondents' perspectives, and experiences about the questions. Semi-structured interviews were used to obtain clarification about personal experiences and respondents' perspectives on Covid-19 mitigation efforts. In the online questionnaire, the identity and answers of respondents are kept confidential, so that respondents can provide information and responses honestly.

The data collected in this study are structural and non-structural steps taken by the community as a form of Covid-19 mitigation. The primary data was collected from the results of filling out the online questionnaire. Analytical induction techniques are used to analyze research data. Analytic induction is used as a data analysis technique with a stringent process in sequence to study the phenomenon under study. The approach used in analyzing data is with a spatial approach, especially in the analysis of patterns and structures. Spatial patterns are used to analyze the distribution of Covid-19 mitigation based on the urbanization level and the existence of the Covid-19 case. While the spatial structure is an analysis that emphasizes the unique expression of Covid-19 mitigation applied to an area, both of these analyzes will comprehensively provide a complete picture of the differences in Covid-19 mitigation between urban and rural areas. 


\section{Result and Discussion}

\subsection{Covid-19 mitigation in urban and rural areas}

Not only show different patterns, but urban and rural areas also show different structures. The differences in the Covid-19 mitigation structure in both areas are shown in Table 1.

Table 1. Differences in Covid-19 Mitigation Structure between Urban and Rural Areas

\begin{tabular}{|c|c|c|c|}
\hline No & Disaster Mitigation & Urban & Rural \\
\hline $\mathbf{A}$ & Structural Mitigation & & \\
\hline 1 & $\begin{array}{l}\text { Build Covid-19 } \\
\text { information center }\end{array}$ & $\begin{array}{l}\text { - involving professional } \\
\text { - } \quad \text { individual space } \\
\text { - } \quad \text { complete facilities }\end{array}$ & $\begin{array}{l}\text { - } \quad \text { rely on local human resources } \\
\text { - emergency space } \\
\text { - } \quad \text { simple facilities }\end{array}$ \\
\hline 2 & Make a portal & $\begin{array}{l}\text { - } \text { guarded by officers } \\
\text { - } \text { made of iron } \\
\text { - } \text { permanent }\end{array}$ & $\begin{array}{l}\text { - } \text { guarded by rural youth } \\
\text { - } \text { made of wood or bamboo } \\
\text { - temporary }\end{array}$ \\
\hline 3 & Spray a disinfectant & $\begin{array}{l}\text { - } \quad \text { by special officer } \\
\text { - } \quad \text { official dosage } \\
\text { - } \quad \text { spray a lot }\end{array}$ & $\begin{array}{l}\text { - by the community } \\
\text { - } \text { man-made; mix ingredients } \\
\text { - } \quad \text { spray a few }\end{array}$ \\
\hline 4 & $\begin{array}{l}\text { Provide sanitation } \\
\text { facilities }\end{array}$ & $\begin{array}{l}\text { - } \quad \text { spread } \\
\text { - } \quad \text { hand soap } \\
\text { - } \text { large amounts }\end{array}$ & $\begin{array}{ll}\text { - } & \text { concentrated } \\
\text { - } & \text { detergent } \\
\text { - } & \text { small amount }\end{array}$ \\
\hline 5 & $\begin{array}{l}\text { Design Covid-19 } \\
\text { website }\end{array}$ & $\begin{array}{l}\text { - manage by professional } \\
\text { - updated information }\end{array}$ & $\begin{array}{l}\text { - manage by rural officials } \\
\text { - out-of-date information }\end{array}$ \\
\hline 6 & $\begin{array}{l}\text { Provide quarantine } \\
\text { facilities }\end{array}$ & $\begin{array}{l}\text { - } \text { complex and specific data } \\
\text { - } \text { supervision by medical } \\
\text { - } \text { hersonel } \\
\text { - } \\
\text { adequate facilities }\end{array}$ & $\begin{array}{l}\text { - basic and general data } \\
\text { - no specific supervisor or none } \\
\text { at all } \\
\text { - not hospital integrated } \\
\text { - inadequate facilities }\end{array}$ \\
\hline B & Non-Structural Mitigat & tion & \\
\hline 1 & Check people health & $\begin{array}{l}\text { - } \quad \text { by medical personnel } \\
\text { - } \quad \text { advanced } \\
\text { - } \quad \text { at random }\end{array}$ & $\begin{array}{l}\text { - by the community } \\
\text { - } \quad \text { simple tools } \\
\text { - } \quad \text { concentrated }\end{array}$ \\
\hline 2 & $\begin{array}{l}\text { Limiting bussines } \\
\text { work-time }\end{array}$ & $\begin{array}{ll}\text { - } & \text { supervised } \\
\text { - } & \text { strict rules } \\
\text { - } & \text { high obedient }\end{array}$ & $\begin{array}{l}\text { - } \text { rarely or unsupervised } \\
\text { - flexible rules } \\
\text { - low obedient }\end{array}$ \\
\hline 3 & $\begin{array}{l}\text { Closing public } \\
\text { facilities and/or } \\
\text { services }\end{array}$ & $\begin{array}{l}\text { - } \quad \text { by city authorities } \\
\text { - } \quad \text { based on regulation } \\
\text { - } \quad \text { easy to close }\end{array}$ & $\begin{array}{ll}\text { - } & \text { by public figures } \\
\text { - } & \text { based on norms } \\
\text { - } & \text { hard to close }\end{array}$ \\
\hline 4 & Giving basic needs & $\begin{array}{l}\text { - directly from government } \\
\text { - } \text { often misdirected } \\
\text { - } \text { quickly distribute }\end{array}$ & $\begin{array}{l}\text { - } \text { managed by the community } \\
\text { - } \text { right target } \\
\text { - } \text { slowly distribute }\end{array}$ \\
\hline 5 & Giving sanitation kit & $\begin{array}{l}\text { - by the government } \\
\text { - } \text { proportionally } \\
\text { - } \text { official dosage }\end{array}$ & $\begin{array}{l}\text { - } \text { provide independently } \\
\text { - free to take } \\
\text { - individual processed }\end{array}$ \\
\hline 6 & Enforce rules & $\begin{array}{ll}\text { - } & \text { conducted by officers } \\
\text { - } & \text { official sanctions } \\
\text { - } & \text { easy to apply } \\
\end{array}$ & $\begin{array}{ll}\text { - } & \text { by the community } \\
\text { - } & \text { traditional sanctions } \\
\text { - } & \text { hard to apply } \\
\end{array}$ \\
\hline
\end{tabular}


Table 1 illustrates the variation in expressions of the application of Covid-19 mitigation between urban and rural areas. Overall, there are fundamental differences from the implementation of Covid-19 mitigation shown by the two areas. In structural mitigation, these differences can be viewed in terms of personnel, material, and allocation. First, the personnel who are the leading sectors in urban areas are professionals who have specific skills, while in rural areas, the majority rely on local human resources. Second, the materials used in designing buildings or technology engineering in urban areas are made from solid raw materials, measured and standard criteria, while in rural areas, they are emergency and without standard measurements. Finally, in terms of allocation, structural mitigation in urban areas is implemented with a large budget so that structural mitigation applied is completely more durable, more complex, and more adequate compared to rural areas.

In non-structural mitigation, significant differences can be viewed in terms of the action, process, and stakeholder compliance. First, the actors who carry out non-structural mitigation in urban areas are the city government, which is an extension of the central government, whereas, in the rural areas, the majority are driven independently by local communities. Second, the process of implementing non-structural mitigation in urban areas is guided entirely by policies issued by the central government, while in rural areas, it is simple, flexible, and dynamic. Finally, in terms of stakeholder compliance, the implementation of non-structural mitigation in urban areas is carried out in a more orderly, more measurable, and more accessible than rural areas.

Different structural mitigation expressions indicate a significant imbalance of human resources, infrastructure, and capital between urban and rural areas. This fact is in line with the research of Tagarirofa (2013), which revealed that the capital gap has a positive effect on the imbalance of urban and rural development. Tironi \& Manriquez (2019) also emphasize the factor of high population knowledge, which contributes significantly to the success of structural mitigation implementation in urban areas [7]. This reality shows that urban areas are more prepared and more reliable in controlling the threat of Covid-19 hazards compared to rural areas.

Different non-structural mitigation expressions indicate the existence of variations in social capital that are essential in terms of cooperation, social relations, and participation. This fact is in line with Putera et al. (2016) research, which revealed that citizen has higher compliance compared to rural communities in following disaster mitigation protocols. Anwar et al. (2020) and Duan et al. (2020) states that policy implementation in rural areas will succeed if local communities are actively involved in it. This reality shows that although people of urban areas are more adaptive in carrying out non-structural mitigation, rural communities are more active in the fight against Covid-19. 


\section{Conclusion}

The development of the Denpasar City area has a significant contribution to the mobility of the population in the hinterland area. The interaction of the city and the hinterland area is indicated by economic and social motives. High urban and rural interactions will increase the rate of population mobility. High population mobility is one of the causes of the spread of COVID-19. Meanwhile, rural areas have various limitations in implementing disaster mitigation. Further research is needed to measure the effectiveness of implementing disaster mitigation in rural and urban areas.

\section{References}

[1] A. Cirjak, "How Coronavirus Has Helped The Planet," 2020. https://www.worldatlas.com/articles/how-coronavirus-has-helped-the-planet.html.

[2] D. Asare-Kyei, F. G. Renaud, J. Kloos, Y. Walz, and J. Rhyner, "Development and validation of risk profiles of West African rural communities facing multiple natural hazards," PLoS One, vol. 12, no. 3, p. e0171921, Mar. 2017, doi: 10.1371/journal.pone.0171921.

[3] D. Roy, S. Tripathy, S. K. Kar, N. Sharma, S. K. Verma, and V. Kaushal, "Study of knowledge, attitude, anxiety \&amp; perceived mental healthcare need in Indian population during COVID-19 pandemic," Asian J. Psychiatr., vol. 51, no. 102083, pp. 1-7, Jun. 2020, doi: 10.1016/j.ajp.2020.102083.

[4] R. Lawrence, L. F. Ching, and H. Abdullah, "Strengths and weaknesses of education 4.0 in the higher education institution," Int. J. Innov. Technol. Explor. Eng., vol. 9, no. 23, pp. 511-519, 2019.

[5] J. Tagarirofa, "An exploration of the disaster-development interface: Towards sustainable development through disaster management," Russ. J. Agric. Socio-Economic Sci., vol. 3, no. 15, pp. 68-72, 2013.

[6] M. Tironi and T. Manriquez, "Lateral knowledge: shifting expertise for disaster management in Chile," Disaster, vol. 43, no. 2, pp. 372-389, 2019.

[7] P. I. Christiawan, "Designing the Mitigation Model of Urban Sprawl Potential Impact in Suburban Denpasar, Bali,” J. Phys. Conf. Ser., vol. 1363, no. 1, p. 12100, 2019.

[8] R. E. Putera, H. Nurasa, and Y. S. Sugandi, "Synergizing stakeholders in reducing risk of earthquake and tsunami-disaster in the most vulnerable area," Int. J. Adm. Sci. Organ., vol. 23, no. 3, pp. 147-155, 2016.

[9] S. Anwar, M. Nasrullah, and M. J. Hosen, "Covid-19 and Bangladesh: challenges and how to address them," Front. Public Heal., vol. 8, no. 154, pp. 1-8, 2020.

[10] R. Duan, J. Liu, C. Wang, and G. Wei, "Influencing Factors of Public Participation in Meteorological Disaster Prevention and Mitigation," Sustainability, vol. 12, no. 8, p. 3108, Apr. 2020, doi: 10.3390/su12083108. 